\title{
知識エ学に基づいた服飾デザインコンサルテーション システムの研究*
}

\section{長町三生 ${ }^{* *}$, 伊藤宏司 ${ }^{* *}$, 辻 敏夫**, 千野高保 ${ }^{* * *}$}

Emotion Technolology is defined as a translation system of human image into physical design elements. This has been applied to a housing design in terms of a knowledge engineering which is named HULIS. This paper is concerned with an application of Emotion Technology to a costume design and a computer representation implemented in a shell of HULIS.

A knowledge-base system has a data base of costume design which is applicable just to young women, and it enables to show a graphic picture very similar to client's image in terms of a reasoning engine of knowledge base.

情緒工学（Emotion Technology）は人間のイメージを物理的デザイン要素へ翻訳するシステムで ある。これは知識工学の手法に基づいて，すでに住宅デザインに応用され，HULIS と名づけられた， 本論は, HULISのシェルにインプリメントしたかたちで, 服飾デザインに応用したものである.

本システムの知識ベースは，若い女性に該当する服飾デザインのデータベースをもち，知識ベース の推論エンジンによって顧客が抱いているイメージに近いグラフィック映像をコンピュータディスプ レイに呈示することができる.

\section{1.はじめに}

生活が豊かになり衣食住の基本的条件が充たされて くると, 次に内容や質の向上が求められるようになる. 衣服についても，素材などが自由に取得できる時代に ふると，自分の気持を自由に表現できる衣服デザイン を求めるようになる，特に衣服は，着衣する人の意思 を外部へ訴求する手段としても利用できるところから， その人のもつイメージが衣服デザインに十分に表現さ れることが望ましい.

ところが, 個人のイメージが尊重され重視されなけ ればならない今日でも, 実際にはデザイナーに委託し

* 昭和 62 年 6 月 16 日受付

** 広島大学 工学部

Faculty of Eng., Hiroshima Univ.

*** 山口女子大学 家政学部

Faculty of Home Economics, Yamaguchi Wowen's College.
て製作するために，最初に願望として抱いていたイメ ージと大幅に異なるものが完成するという, 顧客の要 望とデザイナーの設計との間にミスマッチが発生する こともある.

本研究は, 衣服デザインという人間の感情に大きく 依存する世界が希望どおりに実現できるようにするた めの，考え方とその方法を提案する.

幸いにも我々は“情緒工学 (Emotion Technology)” を長期間にわたって研究し続けだ”. 情緒工学とは“人 間のもつイメージなりデザイン的要望を具体的なデザ イン要素に変換するための翻訳機能をもつシステム” であり，すでにソファ ${ }^{2)}$, 照明 ${ }^{3)}$, 住居4)などに関して研 究を行ってきており, 知識工学的手法を用いてコンピ ュータグラフィックスによる住居のコンサルテーショ ンシステム HULIS を完成させた ${ }^{5)}$. 本論文は, 上記の 目的意識を実現するために, HULISのソフトウエア をシェル（shell）として利用することによって, 顧客 の衣服イメージをデザイン的に実現するコンサルテー 
ションシステムを構築することを目的とする.このシ ステムを名づけて FAIMS (Fashion Image System) という.

\section{2. コンサルテーションシステムの ソフトウェア}

FAIMS のコンサルテーションシステムは, HULIS の知識工学的なコンピュータシステムを利用している. 知識工学の代表例としてエキスパートシステムがよ く引き合いにだされるが，それは“知識べース”と“推 論機構”およびューザーインターフェイスとから成り， 外から与えられる事実ないしデータから, 専門家的知 識を根拠に推論している機構である。

FAIMSの機構は基本的にはエキスパートシステム のそれと同じであるが，詳細には図 1 のとおりであり， 推論機構と色彩調節の理論などの知識ベースのほかに, 知識ベースに付属した形容詞データベース, FAIMS データベース，それにグラフィックスを呈示するグラ フィックスソフトウエアなどから成り立っているのが 特徴である.なお推論機構のなかには, 多くの推論を 矛盾なく整理して結論を導くための黒板モデルを導入 している．簡単にいえば，形容詞処理部，要因決定部， グラフィック表示部の 3 つから成り立っている.

\section{（1）形容同処理部}

これはユーザーが最初に接触する部分である。ユー ザーがもっているイメージ（情緒）を形容詞で表現す ると, そのいくつかの形容詞から推論機構にかけるた めの基本形容詞を選びだす。したがって，この処理部 は特定のイメージの世界にかかわる形容詞のデータべ ースの管理と処理を行う.

\section{（2）要因決定部}

基本形容詞に対してユーザーが抱いているイメージ を推論のうえで決定する部分がこれである。この決定 部には, 情緒工学的研究によって得られたデータベー スがあり，ルールに基づいてデータベースを検索し， 要因值を決定する。これには黒板モデルが関係するこ とがある。

（3）グラフィック表示部

形容詞に基づいて決定された要因を，デザインや色 彩を選んで総合的に表示する部分がこれである。ここ には，デザイン表示データベースと色彩データベース が用意されている。

以上を操作のうえで眺めると, 次のとおりである.

(1) 洋服をつくりたいクライエントは, デザイナー の前で希望するイメージを形容詞で表現する。た とえば“落ちついて”“知的な”洋服をつくりた い,などである。

（2）デザイナーは, クライエントが表出した形容詞 をコンピュータに入力する.コンピュータは 15 個 までの形容詞なら受けつけることができ，それら に最も関係の深い基本形容詞に結びつける。

（3）基本形容詞が決定されると, 推論機構は基本形 容詞に適した要因をデータベースから推論し，デ ザインおよび色彩を特定化する。

（4）それらはディスプレイに表示され，それがクラ イエントに気に入られればそれでよく，そうでな ければ次の候補 (候補は要因値の高い順に 50 種類 決定されている）を呈示するか，あるいはデザイ ン変更ないし色彩変更のルーチンを使って, 好み のイメージに合うように変更する.

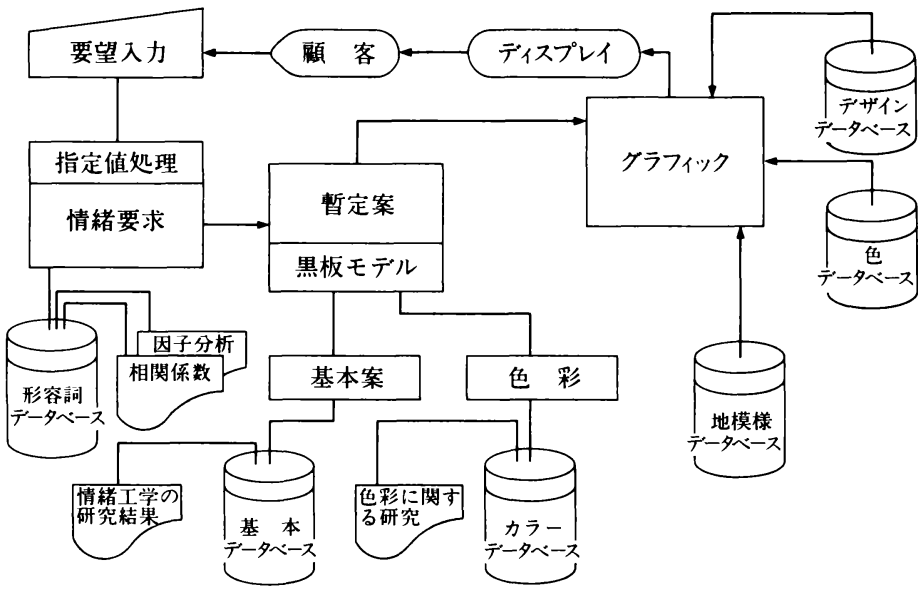

图 1 FAIMSのシステムフローチ ヤート

Fig. 1 A system flow chart of FAIMS. 


\section{3. 服飾デザインの情緒エ学的実験}

\section{3-1. SD 法によるイメージ空間の把握}

情緒工学手法 ${ }^{11}$ 基づいて，まず服飾デザインに関 するイメージ空間を把握することから，研究が始まる．

まず，広辞苑およびファッション関係の雑誌から， 服飾イメージを表現すると思われる言葉（形容詞）を 545 個選びだした。これらを対になるように整え, 意味 が重複するものや，わかりにくいものを整理して 191 の形容詞対を決定した（これを一般形容詞という).

次に, 若い女性が着た様々のスタイルの服飾のスラ イドを作成し, 女子大生 40 名 (18〜22 歳)にそれらを 見せて, 191 形容詞対の SD 尺度で評価させ,それを主 成分分析およびV Varimax 回転を行った。 20 因子が得 られたが，第 7 因子までが全分散の $70 \%$ を占めた。 7 つの因子は(1)安定感の因子, (2)活動性の因子, (3)八イ センスの因子，(4)豪華さの因子，(5)女性らしさの因子， (6)進出性の因子，(7)単調さの因子と命名された.

次に, 191 形容詞対から相関係数が非常に高いもの から,および各因子のなかから, 重複する形容詞を整 理して, 71 の形容詞対を選んで基本形容詞とした(191 対の形容詞では情緒工学的実験が膨大なものになるの で，数を必要なものだけに絞り込んだ).

71 の形容詞対に関して, 改めて主成分分析を行い Varimax 回転を行ったところ, 次の 9 因子を得たが, これらで全分散の $70 \%$ を占め, 共有性も $0.7 \sim 0.9$ と 高かった（表 1 )。

(1)安定感の因子

(2)八イセンスの因子

(3)活動性の因子

(4)豪華さの因子

(6)気軽さの因子

(7)可愛らしさの因子

(8)単調さの因子

(9)進出性の因子

(5)女性らしさの因子

これで理解できるように，191 形容詞対による主成 分分析の結果の因子構造はすべて含まれていることに なる.このイメージ空間は, 服飾の外観イメージと, 着衣での活動性, および時代的感覚の 3 方向を表示し ていることがわかる。

191 個の一般形容詞群と 71 個の基本形容詞群とが, 意味空間の観点からほとんど差異がないことが確認で きたので, 両者の相関係数を基準にして両者を結びつ ける “形容詞データベース”を作成した。

本コンサルテーションシステムの形容詞処理部では, 15 個の形容詞を受け入れて基本形容詞を抽出できる ようにしており, データベース以外の言葉が入ると, ほかの似た表現をしてほしいという表示が現れる。ま
た最初の 3 文字でデータベースと照合するようにして おり, 該当する言葉があれば, データベースの形容詞 を引きだす。相矛盾する形容詞を述べる場合はほとん どないが，仮にそのような場合に遭遇したときには， 人間は連想的に強いイメージを最初に表現する傾向が あることから，早く表現された形容詞群を重視するよ うにしている.

\section{3-2. デザイン要因に関する調査}

\section{（1）服飾デザイン要秦決定と情緒工学的実験}

服飾デザインを考えると, 外出着, 室内着などがあ り, 外出着にもフォーマルウエア, シティウエア, ス ポーツウエアなどと用途別に様々である。また形態的 にみると，ワンピース，スーツ，アンサンブル等々と 多種のスタイルがある゙'. そこで, スーツというスタイ ルのみについて女子大生という年齢範囲に限定したイ メージデータベースを構築することにした。

そこで, 後述するように, スーツのデザイン要素を 情緒工学の手法に基づいて表 2 のように整理し, これ らのスタイルに相当する写真を服飾関係の雑誌から抜 き取り, スライドを作成した。この際, 顔・髪形・八 ンドバッグ・靴などの周辺部分がイメージ調査に影響 を与えないものだけに絞って 74 枚のスライドを作成 した.

前述の 71 個の形容詞を 7 段階評定の SD 尺度に構 成し，スライドに対するイメージを評価させた。被験 者は 120 名の女子大生であり, 2 時間を限度に疲労し ないよう配慮し, 数回に分けて実験を実施した。

実験の結果を基本形容詞を外的基準として林式数量 化理論 I 類にかけ, 71 個の結果を得た. 図 2 は外的基 準 “知的な一知的でない”の結果を示す。この図のよ うに“知的な”と“知的でない”のイメージを明確に 区別する要因が表 2 のどれであるかを示してくれる. ここでは, 色彩が青色で vivid, スカートはフレアなど が偏相関值とスコアが高くなっている.

表 2 のデザイン要素について述べると, 上着の衿に ついてはこまごまとしたデザインが存在するけれども， 図 3 のように，衿なし（丸形・V形）と衿あり（テー ラードカラー）の 3 種類に分類した。 上着のタイプは シングルとダブル, 上着の丈は 3 段階で表現し, 上着 のゆとりはあり・なしの 2 種類, 上着の飾りはありの 場合ではボタン, ライン, ベルトをつけた。

スカートの型は図 4 のように, タイト，フレア，ギ ヤザー, プリーツの 4 種類とし, スカート丈はひざ丈, ふつう丈，長丈として，ひざ上のミニは女子大生のス ーツとしては省いた(図 5 )。スカートの飾りも多く考 えられるが, 図6のようにボタン, ボックス, その他, 
裏 1 服飾デザインの形容詞の主成分分析結果

Tab. 1 Principal component analysis of adjective words related to costume design.

\begin{tabular}{|c|c|c|c|c|c|c|c|c|c|c|}
\hline 形 & 容 詞 & F 1 & F 2 & F 3 & F 4 & F 5 & F 6 & F 7 & F 8 & F 9 \\
\hline 1. たしなみのある & たしなみのない & .895 & .150 & .125 & -.059 & -.022 & -.018 & -.027 & -.002 & .045 \\
\hline 2. 上品な & 下品な & .894 & .198 & .143 & -.015 & -.001 & -.063 & .017 & -.000 & .035 \\
\hline 3. 落ち着いた & 落ち着きのない & .893 & .154 & .086 & -.053 & -.010 & .009 & .013 & .109 & .041 \\
\hline 4. 知的な & 知的でない & .883 & .204 & .138 & -.043 & -.053 & .029 & -.031 & .046 & .043 \\
\hline 5. 清楚な & 清楚でない & .871 & .141 & .224 & -.066 & .045 & -.013 & .036 & .024 & .017 \\
\hline 6. しとやかな & しとやかでない & .869 & .169 & .128 & .042 & .036 & -.062 & .087 & .078 & .031 \\
\hline 7. きちんとした & きちんとしていない & .860 & .135 & .115 & -.055 & -.043 & -.061 & -.041 & -.012 & .032 \\
\hline 8. 物静かな & 物静かでない & .839 & .125 & .084 & .024 & .030 & -.038 & .086 & .132 & .032 \\
\hline 9. スマートな & スマートでない & .767 & .275 & .163 & .107 & -.096 & .021 & .005 & .188 & -.007 \\
\hline 10. エレガントな & エレガントでない & .674 & .304 & .154 & .281 & .037 & -.154 & .169 & .012 & .008 \\
\hline 11. こざっぱりした & ごてごてした & .585 & .143 & .325 & -.107 & .026 & .084 & .004 & .349 & -.041 \\
\hline 12. お嬢さんらしい & お嬢さんらしくない & .583 & .221 & .380 & .106 & .113 & -.158 & .194 & -.141 & .011 \\
\hline 13. やさしい & やさしくない & .582 & .158 & .391 & .090 & .229 & -.159 & .188 & -.013 & -.024 \\
\hline 14. シックな & シックでない & .567 & .224 & .067 & .060 & -.042 & .051 & .023 & .393 & .051 \\
\hline 15. 純真な & 純真でない & .540 & .132 & .427 & .041 & .165 & -.022 & .114 & .014 & -.039 \\
\hline 16. 優美な & 優美でない & .532 & .291 & .295 & .301 & .119 & -.170 & .165 & -.022 & -.014 \\
\hline 17. あっさりした & しつこい & .495 & .160 & .331 & -.105 & .035 & .066 & -.035 & .474 & -.036 \\
\hline 18.スリムな & スリムでない & .439 & .297 & .204 & .257 & -.168 & .050 & .007 & .410 & -.007 \\
\hline 19. 都会的 & 田舎的 & .207 & .854 & .165 & .161 & .024 & .037 & .045 & .051 & .030 \\
\hline 20. センスのある & センスのない & .263 & .847 & .218 & .121 & .073 & .009 & .059 & .056 & .016 \\
\hline 21. すてきな & すてきでない & .279 & .832 & .244 & .119 & .084 & .002 & .081 & .048 & .006 \\
\hline 22. 今風な & 古風な & .161 & .831 & .223 & .142 & .038 & .044 & .038 & .030 & -.012 \\
\hline 23. かっこいい & かっこ悪い & .243 & .819 & .212 & .129 & .009 & .075 & .039 & .078 & .049 \\
\hline 24. あかぬけした & あかぬけしない & .221 & .817 & .216 & .172 & .037 & .001 & .087 & .027 & -.004 \\
\hline 25. 洗練された & 洗練されていない & .215 & .797 & .164 & .220 & .061 & .053 & .055 & .051 & .022 \\
\hline 26. 魅力的な & 魅力的でない & .251 & .791 & .200 & .223 & .108 & .015 & .092 & .036 & -.001 \\
\hline 27.おしゃれな & おしゃれでない & .243 & .786 & .233 & .160 & .066 & -.027 & .122 & .036 & .015 \\
\hline 28. 美しい & 美しくない & .315 & .711 & .233 & .224 & .124 & -.058 & .106 & .068 & .023 \\
\hline 29. 斬新な & 斬新でない & .061 & .644 & .110 & .371 & .032 & .202 & -.042 & -.024 & .039 \\
\hline 30. 粋な & 粋でない & .191 & .618 & .281 & .171 & .009 & .041 & .203 & .203 & .015 \\
\hline 31. 八イカラな & ハイカラでない & .047 & .588 & .178 & .539 & .087 & .099 & .038 & -.041 & .021 \\
\hline 32. 個性的な & 個性的でない & -.048 & .537 & .105 & .489 & .078 & .189 & -.036 & -.024 & .025 \\
\hline 33. モダンな & クラシカルな & .082 & -.318 & -.197 & -.288 & .141 & .055 & -.051 & .092 & .277 \\
\hline 34. 若々しい & 若々しくない & .204 & .222 & .848 & .043 & .085 & .047 & .031 & -.026 & -.040 \\
\hline 35. 明るい & 暗い & .145 & .223 & .841 & .151 & .099 & -.034 & .028 & -.031 & -.040 \\
\hline 36. 健康的な & 非健康的な & .221 & .201 & .835 & .062 & .089 & .079 & .022 & .016 & -.024 \\
\hline 37. 生き生きした & 生き生きしていない & .186 & .237 & .832 & .120 & .080 & .068 & .039 & -.006 & -.027 \\
\hline 38.のびやかな & のびやかでない & .223 & .217 & .814 & .068 & .094 & .102 & -.004 & .060 & -.041 \\
\hline 39. フレッシュな & フレッシュでない & .275 & .211 & .802 & .026 & .089 & .047 & .002 & .083 & -.040 \\
\hline 40. ライトな & ヘビーな & .139 & .175 & .745 & .063 & .112 & .094 & .171 & .111 & -.057 \\
\hline 41. 軽やかな & 重苦しい & .279 & .177 & .718 & .047 & .081 & .057 & -.010 & -.236 & -.072 \\
\hline 42. キュートな & キュートでない & .160 & .223 & .708 & .189 & .138 & .119 & .246 & -.114 & -.009 \\
\hline 43. 活動的な & 非活動的な & .038 & .117 & .613 & .091 & .059 & .476 & .059 & -.017 & -.065 \\
\hline 44. かわいい & かわいくない & .096 & .218 & .569 & .071 & .233 & .182 & .503 & -.147 & -.028 \\
\hline 45. ピュアな & ピュアでない & .098 & .237 & .551 & .093 & .182 & .257 & .536 & -.029 & -.027 \\
\hline 46. 涼しい & 暖かい & .073 & .112 & .496 & .036 & .046 & .157 & .321 & .313 & -.051 \\
\hline 47. ナチュラルな & ナチュラルでない & .222 & .177 & .476 & -.045 & .158 & .180 & .412 & .258 & -.034 \\
\hline
\end{tabular}


表 1 (続き)

Tab. 1 (cont.)

\begin{tabular}{|c|c|c|c|c|c|c|c|c|c|c|}
\hline 形 & 容 詞 & F 1 & F 2 & F 3 & F 4 & F 5 & F 6 & F 7 & F 8 & F 9 \\
\hline 48.華やかな & 華やかでない & .053 & .407 & .145 & .721 & .147 & -.009 & .112 & -.003 & .009 \\
\hline 49.あでやかな & かでない & .030 & .467 & .149 & .688 & .112 & .040 & .076 & -.046 & .014 \\
\hline 50. セクシーな & セクシーでない & .133 & .45 & .017 & .684 & .055 & .073 & .080 & .185 & -.019 \\
\hline 51. ムードのある & ムードのない & .140 & .463 & .032 & .678 & .115 & .055 & .104 & .182 & -.020 \\
\hline 52. ゴージャスな & ゴージャスでない & .029 & .228 & -.031 & .642 & .214 & .134 & -.006 & -.046 & .192 \\
\hline 53．派手な & 地味な & -.199 & .167 & .216 & .592 & -.035 & -.069 & .046 & -.181 & .012 \\
\hline 54. ユニークな & ユニークでない & -.140 & .145 & .037 & .497 & .236 & .425 & -.097 & -.081 & .139 \\
\hline 55. 変化にとんだ & 単調な & -.098 & .222 & .072 & .484 & .172 & .202 & -.063 & -.280 & .300 \\
\hline 56. ドレッシーな & ドレッシーでない & .334 & .225 & .186 & .460 & .093 & -.110 & .241 & .037 & .018 \\
\hline 57. やわらかい & かたい & .066 & .132 & .344 & .173 & .671 & -.175 & .252 & .154 & -.099 \\
\hline 58. ソフトな & ハードな & .076 & .136 & .329 & .174 & .667 & -.168 & .248 & .164 & -.090 \\
\hline 59. 曲線的 & 直線的 & -.095 & -.007 & .117 & .112 & .653 & .069 & .147 & -.212 & -.038 \\
\hline 60.ゆったりした & 窮屈な & .008 & .121 & .134 & .231 & .651 & .192 & -.049 & .049 & -.054 \\
\hline 61.くだけた & すま & -.039 & .079 & .150 & -.065 & .565 & .309 & -.098 & .034 & -.356 \\
\hline 62. 可憐な & 可憐でない & .095 & .312 & .312 & .136 & .383 & -.043 & .348 & -.111 & -.048 \\
\hline 63. ボーイッシュな & $-\cos$ & .100 & .069 & .132 & .175 & .055 & .718 & -.030 & .177 & -.002 \\
\hline 64.スポーティな & ティでない & -.115 & .062 & .321 & .080 & -.040 & .714 & .201 & .010 & -.083 \\
\hline 65. カジュアルな & カジュアルでない & -.016 & .059 & .408 & -.051 & .118 & .512 & .263 & .018 & -.103 \\
\hline 66 . 愛 & 愛ら & .110 & .252 & .552 & .105 & .219 & .186 & .572 & -.103 & -.010 \\
\hline 67. スイートな & スイートでない & .085 & .290 & .396 & .188 & .221 & .041 & .514 & .029 & .035 \\
\hline 68. シンフ & シン & .217 & .085 & .108 & -.277 & .017 & -.017 & -.045 & .557 & .122 \\
\hline 69. 大人っぽい & 子どもっぽい & .249 & .353 & -.113 & .185 & -.178 & -.122 & .022 & .465 & .172 \\
\hline 70. 堅苦 & 它 & .114 & .007 & -.181 & .033 & -.190 & .017 & -.065 & .046 & .819 \\
\hline 71. 気取った & 気取 & .087 & .142 & -.068 & .221 & -.160 & -.142 & .037 & .077 & .794 \\
\hline 四月四 & & 24.01 & 0.10 & 0.41 & 2.00 & 2.10 & 1.02 & 1. & 01 & 1.09 \\
\hline 累積寄与率（\%) & & 34.6 & 46.1 & 55.1 & 58.9 & 61.8 & 64.3 & 66.4 & 68.3 & 69.8 \\
\hline
\end{tabular}

なしの 4 種類とした。したがって，実際にはスカート は図 4 と図 6 の 13 種類, それに図 5 の丈の違い 3 種類 をかけあわせた 39 種類となる。

地模様とは，生地にある模様のことであり，ここで は 20 種類をインプリメントしている.またブラウスの 衿は図 7 のように，9種類のタイプを用意した。

要因決定部には,図 2 のような 71 個の外的基準に関 する多変量解析の結果がデータベースとしてインプリ メントされており, 基本形容詞の決定から推論機構に より，必要なデザイン要素と色彩とが決定される。そ れがグラフィック処理部によって統合されて，ディス プレイに表示される。

色彩については，マンセルシステムに準じたカラー データベースがインプリメントされており，それに日 本色彩研究所のトーン分類とも対応づけられており, 推論機構の指定によって該当するカラーが表示される.

\section{（2）変更の手繶き}

本コンサルテーションシステムでは，1 つの形容詞 に関して上位 50 個のデザインが決定され，そのうちの 最も適切なデザインが表示される，1つの形容詞は常 にポジティブとネガティブの両面をもっているので, したがって 1 つの形容詞で 100 個の候補が用意される。 最初の表示でクライエントのイメージと合わなければ, 次の候補を引きだせばよく，この手順を満足するまで 続ければよい. しかし，これでは 100 個のすべてを検 索しなければならないという無駄が生じるので, もっ と簡単な手続きとして変更処理が用意されている.

表示されたものが満足されない場合のもうひとつの 手順として, スタイル, 色彩, 地模様が随意に変更で きる。スタイルについては, 上述の図 3 から図 7 まで のものがメニューによって選択できるようになってお り，色彩についてはマンセルシステムと同様の表示か 
表 2 FAIMS の服飾デザイン要素

Tab. 2 Costume design elements of FAIMS.

\begin{tabular}{|c|c|}
\hline アイテム & カテゴリー \\
\hline 上着 衿 & $\begin{array}{ll}\text { なし (丸形) } \\
\text { なし (V形) } \\
\text { あり }\end{array}$ \\
\hline タイプ & $\begin{array}{l}\text { シングル } \\
\text { ダブル }\end{array}$ \\
\hline 丈 & $\begin{array}{l}\text { ウエスト } \\
\text { 中間 } \\
\text { ヒップ }\end{array}$ \\
\hline ゆとり & $\begin{array}{l}\text { なし } \\
\text { あり }\end{array}$ \\
\hline 飾り & $\begin{array}{l}\text { なし } \\
\text { ボタン, ライン, ベルト }\end{array}$ \\
\hline スカート 型 & $\begin{array}{l}\text { タイト } \\
\text { フレアー } \\
\text { ギャザー } \\
\text { プリーツ }\end{array}$ \\
\hline 丈 & $\begin{array}{l}\text { ひざ丈 } \\
\text { ふつう丈 } \\
\text { 長丈 }\end{array}$ \\
\hline 飾り & $\begin{array}{l}\text { ボタン } \\
\text { ボックス } \\
\text { その他 } \\
\text { なし }\end{array}$ \\
\hline 地模様 & $\begin{array}{l}\text { あり } \\
\text { なし }\end{array}$ \\
\hline ブラウス 衿 & $\begin{array}{l}\text { なし } \\
\text { ネクタイ } \\
\mathrm{V} ネ ッ ク \\
\text { 丸ネック } \\
\text { スタンド } \\
\text { リボン } \\
\text { ボータイ }\end{array}$ \\
\hline 色相 & $\begin{array}{l}\text { 赤 } \\
\text { 橙 } \\
\text { 黄 } \\
\text { 緑 } \\
\text { 緑青 } \\
\text { 青 } \\
\text { 青紫 } \\
\text { 紫 } \\
\text { 赤紫 } \\
\text { ニュートラル }\end{array}$ \\
\hline トーン & $\begin{array}{l}\text { white } \\
\text { light gray } \\
\text { pale } \\
\text { light } \\
\text { bright } \\
\text { gray } \\
\text { light grayish } \\
\text { vivid } \\
\text { dark gray } \\
\text { dark } \\
\text { deep } \\
\text { black }\end{array}$ \\
\hline
\end{tabular}

知的な一知的でない

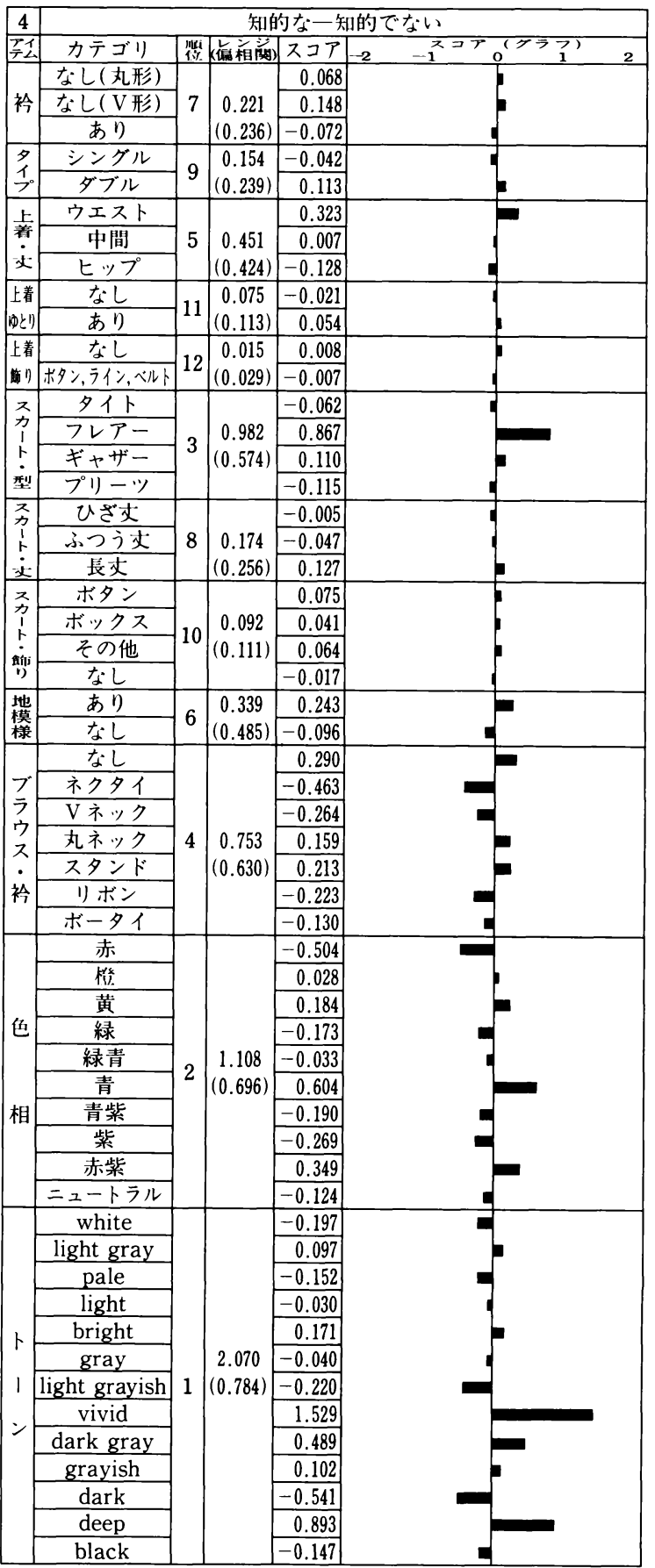

図 2 “知的な一知的でない”の多変量解析結果

Fig. 2 A result of multivariate analysis of "Intellectual-Unintellectual". 
a)なし(丸形)

b) なし(V形)

c)あり

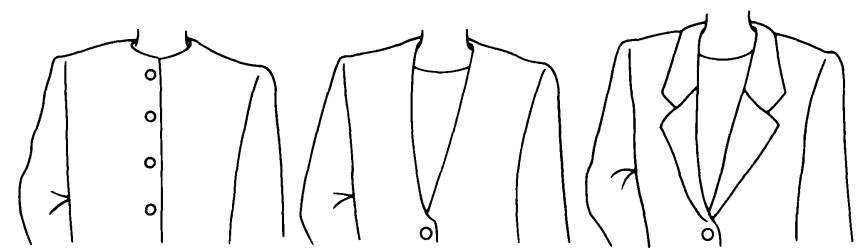

図 3 上着の衿

Fig. 3 Neck design elements.
a)タイト
b) フレアー
c) ギャザー
d) フリーツ
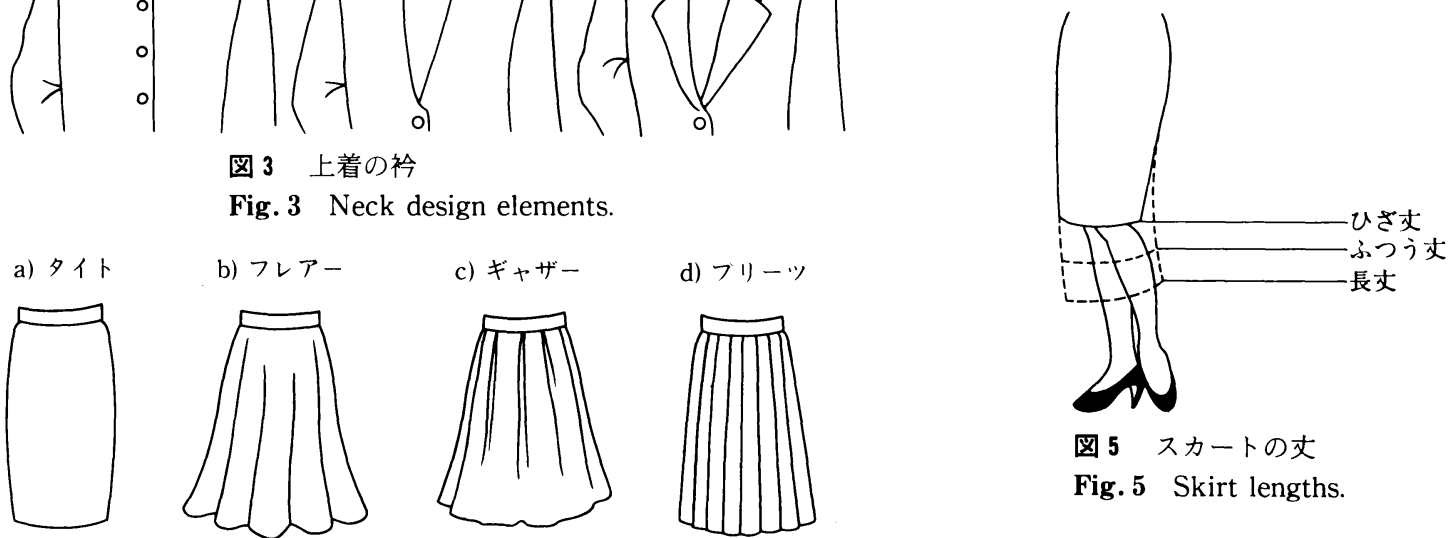

図 5 スカートの丈

Fig. 5 Skirt lengths.

図4 スカートの型

Fig. 4 Types of skirt.

a) ボタン

b) ボックス
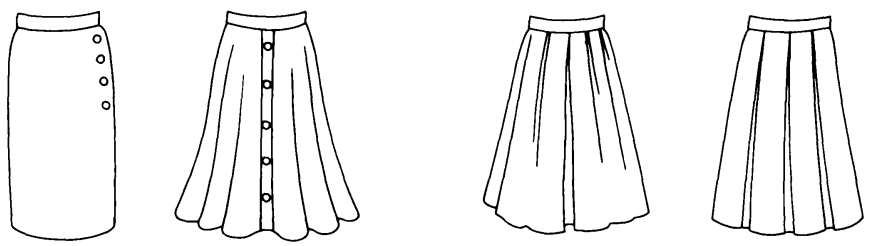

c) その他
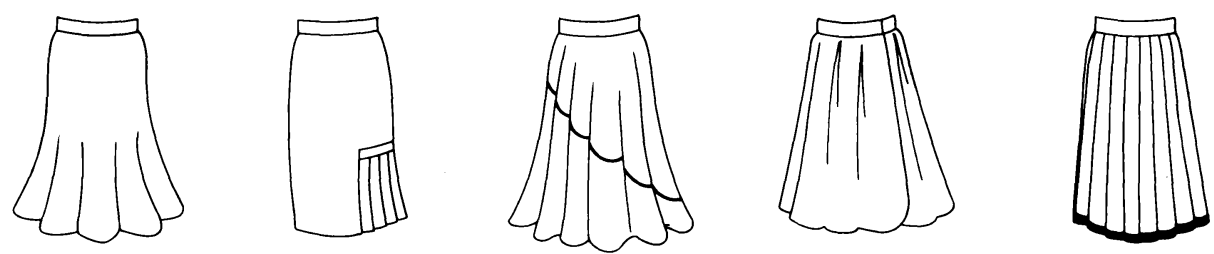

図 6 スカートの飾

Fig. 6 Decorated types of skirt.

a) な

b) ネクタイ
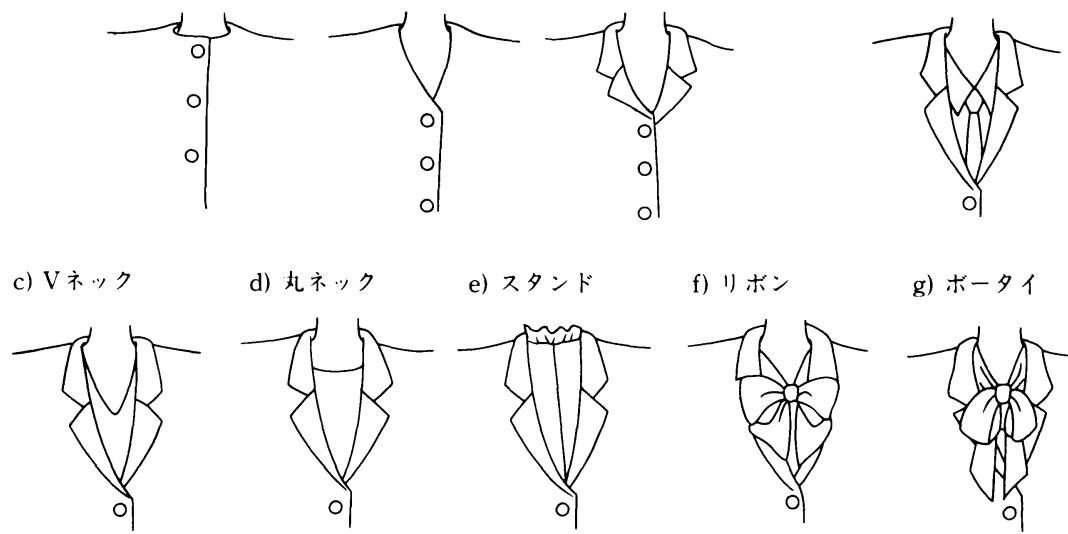

d) 丸ネック

e) スタンド

f) リボン

g) ボータイ

7 ブラウスの衿

Fig. 7 Types of
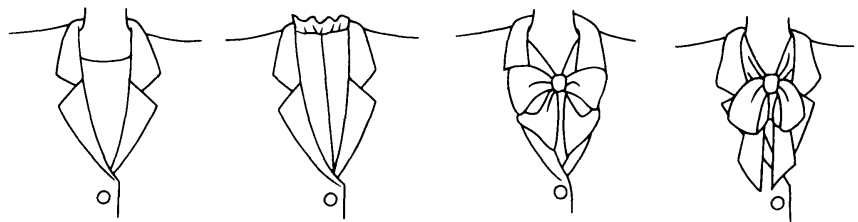

blouse neck. 
ら, 色相, 明度, 彩度が選べるようになっている. 地 模様は 20 種類用意されている。

ただし，100個の候補から順次チェックする場合に は，本システム FAIMS の推論機構による決定である から，クライエントのイメージに近いはずであるが, 上述の変更システムを使用する場合には, 自由に変更 が可能である反面，本システムの推論機構からとびだ しているので, 結果は本システムの目的と離れてしま うことになる。

\section{FAIMS の実例}

図 8 は“知的な” の形容詞で FAIMSを実行させた 結果のひとつである（実際には着色された映像であ る).これは, 図 2 のデー夕をも考慮した推論の結果で ある.クライエントが触れることができる映像は $100 \times 71=7,100$ 種類であり, 図 8 はそのうちの一例で あるが，組み合わせを考えれば数万種類が可能である。

図 9 は“エレガントな”で決定された映像であり, これには薄い桃色がついている，図 8 および図 9 は細 部変更でデザイン変更のためのメニューを表示した例 であり, いずれも色変更のための色指定表を表示した ものである。

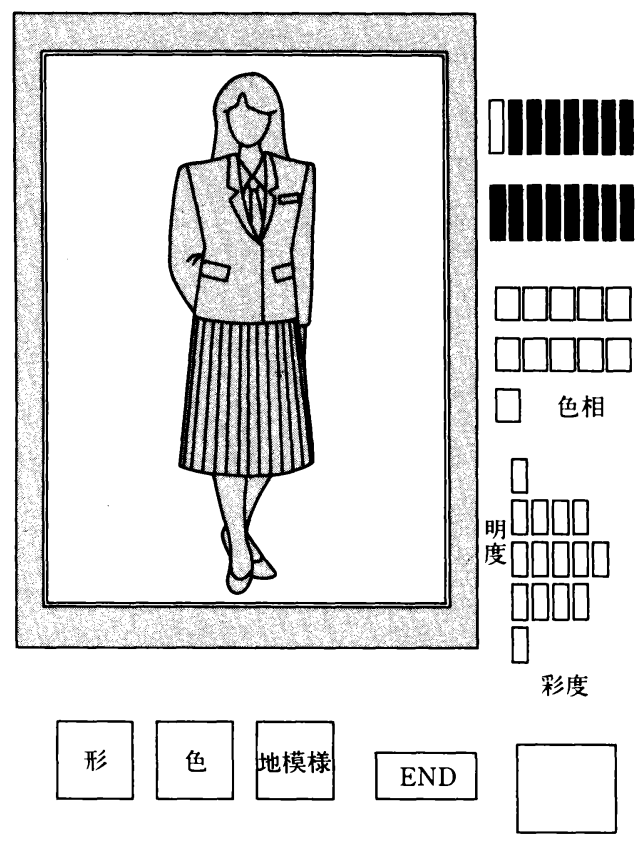

終りたい時は右を押して下さい

图 8 “知的な”の FAIMS の実例

Fig. 8 An example of "Intelligent" in FAIMS

\section{5. 今後の問題}

情緒工学に基づいて構築した知的ソフトウエア HULIS (室内デザインソフト) のシェルに服装デザイ ンに関するデータベースをインプリメントして，服飾 イメージを呈示することを考えたのが，FAIMSであ つた.

FAIMS のなかの形容詞データベースおよびデザイ ンデータベースとカラーデータベースは，本研究のた めに新しく調査され，かつ構築されたものである。実 際に実行させた結果については，イメージ調査に協力 してくれた被験者（女子大生）による評価はおおむね 良好であった。というのも，彼女たちがイメージを表 示し, その統計結果がデータベースとして構築されて いるのであるから，当然といえば当然である。そして， シェルとしてのエキスパートシステムも，この種の情 緒工学的な知的ソフトウエアとしては, 十分に実用に 供する能力があることも判明した。

ただし FAIMSに関しては，服飾スタイルをスーツ だけに限定し，しかも情緒工学的なデータベースは女 子大生という年齢に限られている。したがって, 本研 究で服飾デザインのイメージ化に本システムが使用可

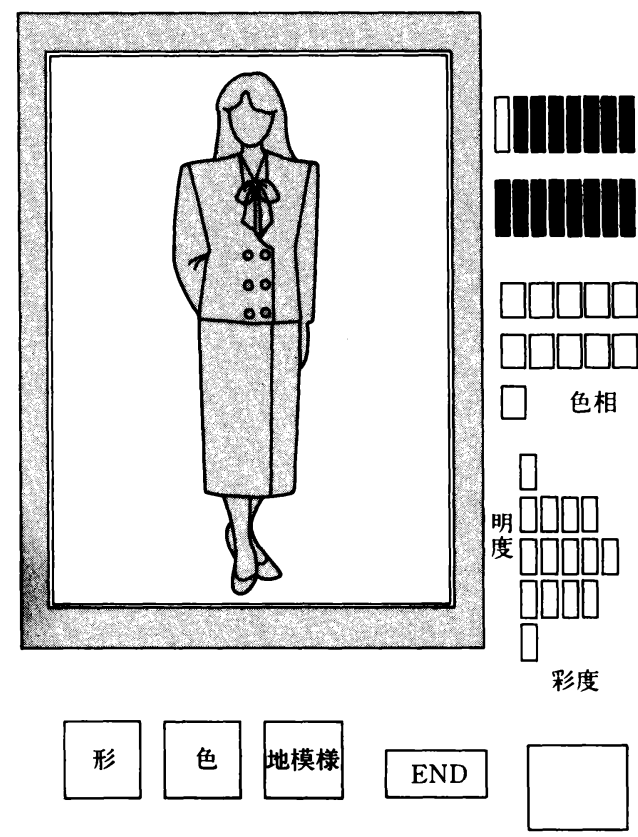

終りたい時は右を押して下さい

図 9 “エレガントな”の FAIMS の実例

Fig.9 An example of "Elegant" in FAIMS. 
能であることはわかったけれども，これで実用に耐え ることにはならない.

そのためには，もっと幅広い年齢層でデー夕を収集 するか, もしくは専門の服飾デザイナー（エキスパー ト）の服飾デザイン知識を知識表現することが必要で あろう。あるいは，クライエントにも身体をはじめと する体型の個人差があり，その個人差をも考慮したう えでのイメージ化を推論することも必要である。その 意味で, FAIMS は情緒工学的なイメージ化に関して の第一歩を踏みだしたところであるといえるであろう. すでに体型のデータベースの作成にかかっているので, 今後, 実用化に耐えうるための必要なデータベースを 充足することによって, FAIMSが一般クライエント に供される日がくるであろう。

最後に, エキスパートシステムは, 特定の専門家の 知識によって診断などがなされるシステムであるが, えてして一般クライエントとデザイナーとの間にミス マッチが生じやすいことは, すでに指摘した。情緒工 学がこのようなミスマッチを防ぐための知的インター フェイスであることを目的としているのであるから， むしろ専門家の知識と一般のクライエントのイメージ
の双方から目的とするイメージを決定するという方式 が, 最も望まれるシステムであろう。

\section{参考文献}

1）長町三生: 情緒工学とその応用, 人間工学, 2(6), 319 324, 1986.

2）長町三生，小松一雄，売れる製品の要素研究， 広島商工会議所技術開発委員会報告書, 1977 .

3）長町三生, 伊藤宏司, 福場良之, 辻 敏夫, 田 㴊義彦, 入枝輝昭: 室内照明の情緒工学的研究, 人間工学, $21(5), 265 \sim 270,1985$.

4）長町三生, 瀬沼 勲, 岩重律子：室の雾囲気に 関する感情分析, 人間工学, 13(1), 7 14, 1977.

5）長町三生, 伊藤宏司, 福場良之, 辻 敏夫, 川 本浩史 : 知識工学手法によるインテリア・コンサ ルテーション・システムの開発, 人間工学, $22(1), \quad 1 \sim 8,1986$.

6）飯塚弘子, 万江八重子, 香川幸子：服装デザイ ン論, 文化出版局, 1985. 